\title{
Penguatan Lembaga Saniri dalam Pembangunan Masyarakat Adat di Ambon
}

\author{
Dr. Yustina Trihoni Nalesti Dewi, S.H., M.Hum. \\ (Ketua Pusat Studi Urban UNIKA Soegijapranata Semarang)
}

Ambon memiliki keunikan sebagai satu-satunya kota di Indonesia yang mengelola 3 sub-sistem pemerintahan secara sekaligus yaitu terdiri dari 20 kelurahan, 8 desa, dan 22 desa adat (Negeri). Ini membuktikan ciri khas Ambon, bahwasanya kemajemukan bukan saja pada masyarakatnya tetapi juga pada sistem pemerintahannya. Peraturan Daerah (Perda) Kota Ambon Nomor 8 Tahun 2017 tentang Negeri sebagai implementasi Undang-Undang Nomor 6 tahun 2014 tentang Desa, diharapkan dapat mewujudkan otonomi desa adat yang asimetris berbasis masyarakat adat dengan kekhususannya dalam hal eksistensi, kelembagaan dan fungsinya yang berbeda dengan desa atau kelurahan.

Lembaga Saniri adalah inspirasi otentik dan jantung masyarakat adat Ambon yang dalam sejarahnya mempunyai peran strategis dan pengaruh kuat secara kultural, politik, maupun sosial untuk menciptakan keteraturan dan keseimbangan. Karena dibangun dan dipelihara oleh masyarakat itu sendiri, yang dalam struktur keanggotaannya mempunyai kedekatan dan mencerminkan aspirasi dan keterwakilan masyarakat adat, maka Saniri memperoleh legitimasi menjalankan perannya secara maksimal demi kehidupan yang serasi dan harmonis dengan memberdayakan kearifan lokal dan hukum adat dalam menyelesaikan masalah publik, masalah antar-individu maupun dalam merumuskan kebijakan melalui mekanisme musyawarah sehingga semua aspirasi dari tiap-tiap warga dapat terwakili. Namun sayangnya peran ini direduksi sedikit demi sedikit pada masa Orde Baru yang mencabut Saniri dari keutuhan tatanan kosmologi yang menjadi inti kesakralannya, menggerogoti kapasitas dan kewibawaan Saniri sebagai otoritas harmoni.

Kini Saniri tengah membangun dirinya sebagai lembaga yang mempunyai fungsi sentral dan strategis dalam masyarakat adat yang bekerja bersama-sama masyarakat menyelesaiakan setiap persoalan yang ada. Revitalisasi Lembaga Saniri mengarahkan suatu proses perubahan dimana hukum yang berlaku menjamin dan memberi kemampuan pada Saniri untuk menggunakan hukum dalam rangka meningkatkan hak-hak tradisionalnya dan semua kepentingannya sebagai aktor perubahan sosial. 
Dengan demikian, penguatan kapasitas Saniri bersifat sistemik: mencerminkan relasi top-down yaitu antara Negara dengan Saniri dimana Negara memberi jaminan eksistensi dan fungsi Saniri, sehingga Saniri harus diberi pengakuan yang bersifat yuridis formal. Disamping relasi yang bersifat top-down, penguatan Saniri juga mencakup relasi yang bersifat bottom-up dimana Saniri dapat mengembangkan kapasitasnya dan memberdayakan dirinya sendiri sebagi aktor rekonstruksi sosial dengan mengundang partisipasi masyarakat seluas-luasnya melalui segala inisiatif, keputusan-keputusan yang dibuatnya.

Integrasi penelitian dan pengabdian yang dilakukan bertujuan mengembalikan dan mengembangkan kapasitas Saniri, baik kapasitas lembaganya maupun kapasitas anggotanya. Kegiatan dimulai dengan penguatan lembaga Saniri melalui pembenahan legislasi dalam sinergi bersama Pemerintah Kota Ambon. Disamping itu, dilakukan juga penguatan kapasitas anggota Saniri melalui pendidikan dan pelatihan, sosialisasi, dan pembimbingan teknis dengan bersinergi dengan sebuah lembaga masyarakat (Institut Tifa Damai Maluku) yang sudah mempunyai pengalaman panjang dalam melakukan pendampingan masyarakat di Ambon. Pelatihan dan pembimbingan teknis ditujukan untuk meningkatkan kesadaran anggota Saniri di 22 Negeri dalam mengatur, mengelola, dan menyelesaikan setiap permasalahan yang ada di negeri untuk mendorong rekonsiliasi berbasis Negeri dengan mengedepankan partisipasi masyarakat dan kearifan lokal. 